\title{
POLYMORPHISM OF GENES OF THE PROTEIN AND LIPID EXCHANGES IN MODERN UKRANIAN BREEDS OF CATTLE BRED FOR DAIRY PRODUCTIVITY
}

\author{
Yulia V. Gritsienko', Michael I. Gill,"\#, Liubov Denisyuk ${ }^{3}$, and Igor Yu. Gorbatenko ${ }^{2}$ \\ ${ }^{1}$ Nikolaev Scientific-Research Expert Forensic Center of the Ministry of Internal Affairs of Ukraine, 2-A 1-Voyennaya, \\ Mykolayiv, 54003, UKRAINE \\ ${ }^{2}$ Mykolayiv National Agrarian University, 9 Georgy Gongadze, Mykolayiv, 54010, UKRAINE \\ ${ }^{3}$ Kyiv Clinical Ophtalmology Hospital, Microsurgery Center, Avenue Lubomir Guzar 3, Kyiv, 01135, UKRAINE \\ \# Corresponding author, michaeligill@ukr.net
}

Communicated by Isaak Rashal

\begin{abstract}
Genetic structure of animals of several Ukrainian modern breeds analysed by genes of protein and lipid exchange CSN3 (kappa-casein), BLG (betalactaglobulin), LEP (leptin), Pit-1 (pituitery transcription factor), TG-5 (thyroglobulin) were investigated in cows of three domestic breeds (Ukrainian Red Dairy, Ukrainian Black-speckled Dairy, Ukrainian Red-speckled Dairy). Polymerase chain reaction, followed by restriction fragment length polymorphism was used for the molecular-genetic analysis.
\end{abstract}

Key words: structural genes, homozygosity, genetic equilibrium, milk productivity.

\section{INTRODUCTION}

Development of methods using genetic diagnostics in the practice of cattle breeding is an urgent task of fundamental and applied genetics. A necessary precondition for carring out DNA-diagnostics is genetic polymorphism, which is the basis of hereditary change in an organism.

DNA markers provide exact tools to investigate genetics of varieties. Use of the polymorphic area of DNA as marker systems allows testing the genetic unsteadiness at the molecular level of organisation in organisms at the level of genes, that is genotype. Using DNA markers in selection of pedigree cattle gives the opportunity of determining their real genetic potential. Further, genotyping of organisms allows to conduct selection by identifying valuable alleles of different genes within farm populations. The DNA markers give a possibility of identification of any DNA fragment, which is necessary for marker assisted selection (MAS) (Sulimova et al., 2002).

These diagnostic tools are useful for determining potential improvement of cattle breeds, and have become required procedures in Europe, and are expanding in dairy cattle breeding in Ukraine.

Due to the market demand for a higher quality of milk, especially for the quantity of protein, its qualitative composition, and for cheese-making characteristics of milk, breeding requires use of genetic markers associated with qualitative and quantative signs of milk production. Thus, allelic variants of genes associated with protein and milk fat production are important markers in dairy cattle (Kopylov, 2011).

The search for new molecular-genetic markers of genes associated with key traits and their mapping on chromosomes in farm animals is aimed to identify the genetic potential of animals, irrespective of age, sex, and physiological state and allows breeding at the level of DNA (Kim et al., 2001). Research on breeds of cattle to determine the main loci of quantitative traits associated with milk production has focused on the main genes affecting qualitative and technologial parameters of milk (Kopylov, 2011).

The aim of this work was to study polymorphism in genes of protein and lipid exchanges - CSN3 (kappa-casein), 
$B L G$ (beta-lactoglobulin), LEP (leptin), sand Pit-1 (pituitary transcription factor), $T G-5$ (thyreoglobulin) in cows of three native breeds within a pedigree farm and to determine their genetic structure associated with milk productivity loci. The study was carried out on three Ukrainian breeds in a farm with the same feeding and diet conditions, located in the southern region of the country. The examined loci directly affect the qualitative and quantitative indicators of milk productivity.

\section{MATERIALS AND METHODS}

Milk breeds of cattle Ukrainian Red Dairy (URD, $n=32$ heads), Ukrainian Black-speckled Dairy (UBSD, $n=32$ heads), and Ukrainian Red-speckled Dairy (URSD, $n=28$ heads) in the herd of the pedigree farm PSP "Kolos-2011" in Ochakov district, Mykolaiv region, were tested.

Genomic DNA was isolated from peripheral blood of animals as previousy described (Maniatis et al. 1984; Zinovieva 2002), using the standard commercial set "DNA sorb B" produced by "Amplisens" (Russia), according to the recommendation of producer. The concentration of DNA was determined by electrophoresis in $2 \%$ agarose gel. Polymorphism of the structural genes in extracted DNA was determined by electrophoretic distribution of proteins in the starched horizontal gel and in the vertical polyacrylamide gel with further histochemical painting.

The characteristics of polymorphism of the tested genes were determined by RFLP (Restriction Fragment Length Polymorphism) (Alexander et al, 1988; Grodziker et al., 1974; Sulimova et al., 2002). The PCR reactive mixture $(10 \mu \mathrm{l})$ contained $4.3 \mu \mathrm{l} \mathrm{dH2O}, 2.0 \mu \mathrm{l}$ PCR buffer $(15 \mathrm{~m}$ Mg-1.0 mol); $0.8 \mu \mathrm{l}$ of $2 \mathrm{mM}$ dNTP mixture, $0.8 \mu \mathrm{l}$ of two primers (70 ng each), $0.1 \mu \mathrm{l}$ Taq-polymerase ( $1 \mathrm{ml} / 1000$ $\mathrm{U})$ and $2.0 \mu \mathrm{l}$ DNA (50-100 $\mathrm{ng}$ ). The restriction products were separated by electrophoresis in $2 \%$ agarose gel with further staining by bromide ethidium (Oblap et al., 2010). Visual evaluation was made with a transilluminator in ultraviolet light and electrophoregrams taken by a digital camera was applied. Differentiation of amplicons by size was carried out with the help of markers of molecular weight GeneRulerTM 50 bpDNALadder, SM0378 ("Fermentas", Lithuania; Kopylov 2011).
The temperature conditions and number of cycles of PCR-amplification required for every gene were determined separately. Restrictases selected for every locus were used for analysis of polymorphism of the structural loci $\kappa-C n$, $\beta L G, T G, P I T-1$ and $L E P$ (Table 1) after PCR-analysis. The composition of the restriction mixture was: $\mathrm{H}_{2} \mathrm{O}-3.0 \mu \mathrm{l}$, buffer (10 mM MgCl $2,100 \mathrm{mM} \mathrm{KCl}, 0.1 \mathrm{mg} / \mathrm{ml} \mathrm{BSA})-$ $1.5 \mu \mathrm{l}$, restrictase $-0.5 \mu \mathrm{l}$, and PCR-product $-10 \mu \mathrm{l}$.

Amplification of fragments of tested genes was carried ouf with using the specific primeres, given in Table 1 .

The following parameters of genetic structure were determined: frequency of alleles and genotypes, the level of real $\left(H_{o}\right)$ and expected heterozygosity $\left(H_{e}\right)$, and index of polymorphism $(P I C)$. Estimation of compliance of genotype frequency to the equilibrium Hardy-Weinberg equation was carried out by the Pearson $\left(\chi^{2}\right)$ criterion. The genetic differentiation of the tested population was estimated by the fixation index $\left(F_{I S}\right)$, which quantitatively reflects declination from panmixis and is determined by relation of average real heterozygosity to the average expected. Population genetic and biometrical analysis of the obtained results was conducted using the $\chi^{2}$, Student's T, and Fisher's exact tests.

Statistical processing of the data was conducted using the software Microsoft Excel 2013 and integration of the GenAlEx 6.5 add-on (http://biology-assets.anu.edu.au/ GenAlEx/Download.html). Analysis of other indices was conducted using IBM SPSS Statistics V24.0 package (https://wwwibmcom/support/knowledgecenter/en/ SSLVMB_24.0.0/spss/product_landmg.html).

\section{RESULTS}

Distribution of the allelic variants of the structural genes of the protein and lipid exchange in the above-mentioned breeds are given in Table 2.

Two alleles of gene kappa-casein A and B and three genotypes were revealed: AA with fragment length 273 n.p., AB with restriction fragments of length $-273,133,91$ and 49 n.p. and genotype BB with restriction fragments of length 133, 91, and 49 n.p. (Fig. 1).

Table 1. Nucleic succession of primers and restrictases

\begin{tabular}{|c|c|c|c|}
\hline Gene & Succession of primers $5^{\prime} \rightarrow 3^{\prime}$ & Restrictase & Reference \\
\hline$\kappa-C n$ & $\begin{array}{l}\text { 5'-GAAATCCCTACCATCAATACC-3' } \\
\text { ta 5'CCATCTAC CTAGTTTAGATG-3' }\end{array}$ & Hinf1/HindIII & Eggen, 1998, Pider, 1991 \\
\hline$\beta L G$ & $\begin{array}{l}\text { 5'-GTG CTGGACACCGACTACAAAAAG-3' } \\
\text { ta 5'-GCTCCCGGTATATGACCACCCTCT-3 }\end{array}$ & Hae III & Medrano, 1990 \\
\hline$T G-5$ & $\begin{array}{l}\text { 5'-GGGGATGACTACGAGTATGACTG-3' } \\
\text { Ta 5'-GTGAAAATCTTGTGGAGGCTGT-3' }\end{array}$ & PsuI & Alison, 2007 \\
\hline$L E P$ & $\begin{array}{l}\text { 5'-GTCACCAGGATCAATGACAT-3' } \\
\text { ta 5'-AGCCCAGGAATGAAGTCCAA-3' }\end{array}$ & Sau3AI & Pomp, 1997 \\
\hline Pit-1 & $\begin{array}{l}\text { 5'-CAAT GAGAAAGTTGGTGC-3' } \\
\text { ta 5'-TCTGCATTCGAGATGCTC-3' }\end{array}$ & HinfI & Moody, 1996 \\
\hline
\end{tabular}


Table 2. Distribution of allelic variants by loci $C S N 3, B L G, L E P, P i t-1$ and $T G-5$

\begin{tabular}{l|c|c|c}
\hline \multirow{2}{*}{$\begin{array}{c}\text { Locus, } \\
\text { allele }\end{array}$} & \multicolumn{3}{c}{ Breed } \\
\cline { 2 - 4 } CSN3(n) & $\begin{array}{c}\text { Ukrainian Red } \\
\text { Dairy }\end{array}$ & $\begin{array}{c}\text { Ukrainian Black- } \\
\text { speckled Dairy }\end{array}$ & $\begin{array}{c}\text { Ukrainian Red- } \\
\text { speckled Dairy }\end{array}$ \\
$A$ & 16 & 15 & 15 \\
$B$ & 0.81 & 0.80 & 0.73 \\
$B L G(n)$ & 0.19 & 0.20 & 0.27 \\
$A$ & 16 & 15 & 15 \\
$B$ & 0.59 & 0.27 & 0.27 \\
$P i t-1(n)$ & 0.41 & 0.73 & 0.73 \\
$A$ & 16 & 15 & 15 \\
$B$ & 0.31 & 0.37 & 0.50 \\
$T G-5(n)$ & 0.69 & 0.63 & 0.50 \\
$C$ & 16 & 15 & 15 \\
$T$ & 0.91 & 0.97 & 0.93 \\
$L E P(n)$ & 0.09 & 0.03 & 0.07 \\
$C$ & 16 & 15 & 15 \\
$T$ & 0.56 & 0.37 & 0.20 \\
& 0.44 & 0.63 & \\
\hline
\end{tabular}

Among populations of the three cattle breeds (Table 3), the frequency of allele $\mathrm{A}$ in the group of cows of Ukrainian red dairy breed was 0.813 . More than half of cows of this breed were homozygotic for allele AA and 37.5-40.0 per cent of the tested animals of the breeds were carriers of the heterozygotic genotype $\mathrm{AB} C S N 3$, and only representatives of the Ukrainian red-speckled dairy breed were characterised by the presense of female cows with homozygotic genotypes BB (7.7 per cent), which may be explained by their origin.

The distribution of the locus CSN3 is uneven among the cattle breeds with greater frequency of heterozygotes (62.5 percent) among the cows of Ukrainian Red Dairy breed. The frequency of the desired allele CSN3 B is low $(0.188-0.267)$ because of wide use of the Holstein breed in breeding for greater yield in cows. In Ukrainian Red Dairy and Ukrainian Black-speckled dairy cows, the homozygote BB is not found. Comparison of frequency of the allele showed that in the tested breeding stock of this breed in the pedigree farm PSP "Kolos-2011" the allele CSN3 B had 2.7-4.3 times higher frequency than in other farms and, opposite, the lowest frequence in cows of the Red-speckled colour breed. There was a loss of genetic equilibrium in locus CSN3 in favour of homozygotes in cows of breeds of Ukrainian Red Dairy and Ukrainian Black-speckled Dairy,

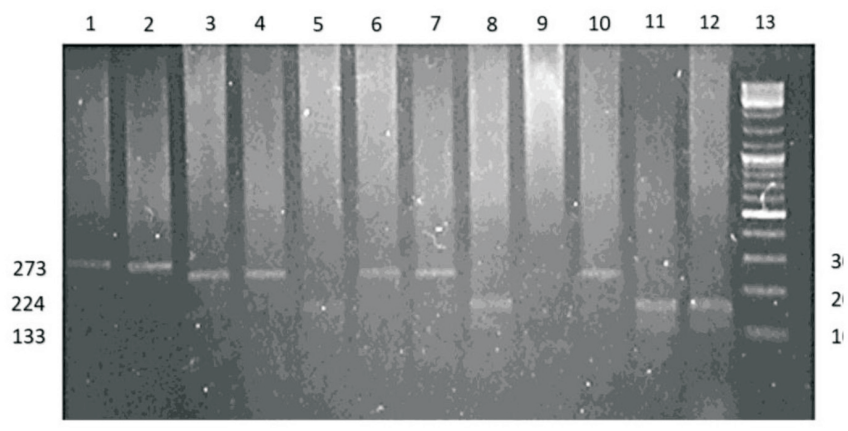

Fig. 1. Electrophoregramme of the products of restriction of amplificated fragments of kappa-casein gene of locus CSN3

(1 - product of amplification of gene; 2 - genotype AA; 3,4,6,7,10 - genotype $\mathrm{AB} ; 5,8,11,12$ - genotype $\mathrm{BB} ; 13$ - marker of molecular mass)

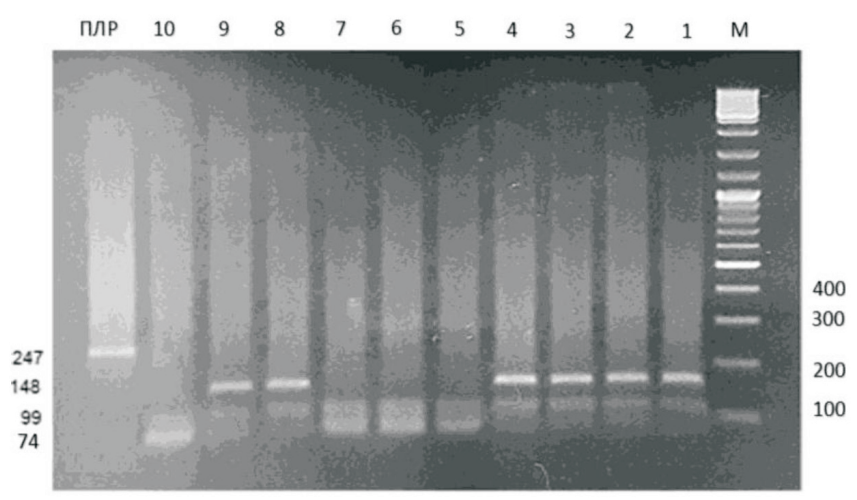

Fig. 2. Electrophoregramme of the restriction products of amplificated fragments of beta-lactoglobulin gene by locus $B L G$

(1, 2, 3, 4, 8, 9 -genotype AB; 5, 6, 7, 10 - genotype BB; PCR-product of amplification; $\mathrm{M}$ - molecular mass marker)

which is not typical for cows Ukrainian Red-speckled Dairy of the same age, shown by the indices $H_{o}$ and $H_{e}$. This was confirmed by the fixation index $(1.1 \%)$ obtained for Ukrainian Red-speckled Dairy animals, compared with to 19.2 and $20.8 \%$ for the others breeds.

Figure 2 shows the results of restriction of products of amplification of beta-lactoglobulin gene.

Three restrictive fragments with length 148, 99, and 74 n.p. belong to genotype $\mathrm{AB}$, and two fragments with length 99 and 74 n.p. to genotype BB. The protein contains sulphur ( $7-12 \%$ of the total protein content). The produced $\beta$-globulin contained in the serum of blood is transmuted in milk is globulin of milk. Globulin is also present in milk in the

Table 3. Polymorphism of the gene CSN3 in cows of Ukrainian breeds

\begin{tabular}{|c|c|c|c|c|c|c|c|c|c|c|c|c|c|}
\hline \multirow[t]{3}{*}{ Breed } & \multirow[t]{3}{*}{$n$} & \multicolumn{6}{|c|}{ Frequency of genotype } & \multirow{3}{*}{$\begin{array}{c}\text { Frequency } \\
\text { of allele } \\
\text { A/B }\end{array}$} & \multicolumn{2}{|c|}{ Heterozygosity } & \multirow[t]{3}{*}{$\chi^{2}$} & \multirow[t]{3}{*}{$P I C$} & \multirow[t]{3}{*}{$F_{I S}$} \\
\hline & & \multicolumn{2}{|c|}{ AA } & \multicolumn{2}{|c|}{$\mathrm{AB}$} & \multicolumn{2}{|c|}{$\mathrm{BB}$} & & $H_{o}$ & $H_{e}$ & & & \\
\hline & & $n$ & $\%$ & $n$ & $\%$ & $n$ & $\%$ & & & & & & \\
\hline URD & 16 & 10 & 62.5 & 6 & 37.5 & 0 & - & $0.813 / 0.187$ & 0.375 & 0.315 & 0.852 & 0.305 & -0.192 \\
\hline URSD & 15 & 8 & 53.3 & 6 & 40.0 & 1 & 6,7 & $0.733 / 0.267$ & 0.400 & 0.405 & 0.008 & 0.391 & 0.011 \\
\hline UBSD & 15 & 9 & 60.0 & 6 & 40.0 & 0 & - & $0.800 / 0.200$ & 0.400 & 0.331 & 0.938 & 0.320 & -0.208 \\
\hline
\end{tabular}


Table 4. Polymorphism by genome $B L G$ of cows of Ukrainian breeds

\begin{tabular}{|c|c|c|c|c|c|c|c|c|c|c|c|c|c|}
\hline \multirow[t]{3}{*}{ Breed } & \multirow[t]{3}{*}{$n$} & \multicolumn{6}{|c|}{ Frequency of genotype } & \multirow{3}{*}{$\begin{array}{c}\text { Frequency } \\
\text { of allele } \\
\text { A/B }\end{array}$} & \multicolumn{2}{|c|}{ Heterozygosity } & \multirow[t]{3}{*}{$\chi^{2}$} & \multirow[t]{3}{*}{ PIC } & \multirow[t]{3}{*}{$F_{I S}$} \\
\hline & & \multicolumn{2}{|c|}{ AA } & \multicolumn{2}{|c|}{$\mathrm{AB}$} & \multicolumn{2}{|c|}{$\mathrm{BB}$} & & $H_{o}$ & $H_{e}$ & & & \\
\hline & & $n$ & $\%$ & $n$ & $\%$ & $n$ & $\%$ & & & & & & \\
\hline URD & 16 & 7 & 43.8 & 5 & 31.2 & 4 & 25.0 & $0.59 / 0.41$ & 0.312 & 0.498 & 1.985 & 0.482 & 0.372 \\
\hline URSD & 15 & 3 & 20.0 & 2 & 13.3 & 10 & 66.7 & $0.27 / 0.73$ & 0.133 & 0.405 & 6.516 & 0.391 & 0.670 \\
\hline UBSD & 15 & 1 & 6.7 & 6 & 40.0 & 8 & 53.3 & $0.27 / 0.73$ & 0.400 & 0.405 & 0.008 & 0.391 & 0.011 \\
\hline
\end{tabular}

form of membranes of fat balls, and with increasing fat content, the proportion of globulin is increased (GodovacZimmerermann et al., 1990).

The Ukrainian Red Dairy breed estimated in our research (Table 4) has almost even distribution of the allelic variants: frequency 0.59 for $B L G \mathrm{AB}$ and 0.41 for $B L G \mathrm{~B}$. However, the frequency of homozygotes of genotype AA was 0.438 , $\mathrm{BB}-0.250$. The cows of the Ukrainian Red-speckled Dairy breed of the same age had a greater quantity of homozygotes BB (frequency 0.667), and the frequency of B was 0.73 , that is, 66.7 per cent of animals were homozygotic for allele B. The Ukrainian Black-speckled Dairy breed also had greater frequency of allele B (0.73); the frequency of animals homozygotic for allele B was $53 \%$.

The largest frequency of homozygotes (43.8\% genotype AA) for genome BLG was observed for the cows of the Ukrainian Red Dairy breed, compared with $66.7 \%$ genotype BB in the Ukrainian Red-speckled Dairy breed and 53.3\% genotype BB in Ukrainian Black-speckled Dairy cows. Deviation of real heterozygosity for locus $B L G$ was expressed clearly in animals of the Ukrainian Red-speckled Dairy breed (0.133-0.405), indicating displacement of the genetic equilibrium. The fixation index indicated a considerable advantage of homozygotes over heterozygotes in cows of the Ukrainian Red Dairy (37.2 per cent) and Ukrainian Redspeckled Dairy (67.0 per cent) breeds, but this was not seen in this locus for animals of the Ukrainian Black-speckled Dairy breed, which were supposed to be genetically free from gene complexes of control of the red colour.

The results of restriction analysis of the products in amplification of the leptin gene is shown in Figure 3.

The Ukrainian Red-speckled Dairy breed had greater frequency of allele $\mathrm{C}(0.800)$ and homozygote CC (0.667), and the frequency of heterozygote CT was 0.267 (Table 5). For the Ukrainian Black-speckled Dairy breed there was a higher frequency of $\mathrm{T}(0.63)$, and the frequency of heterozy-

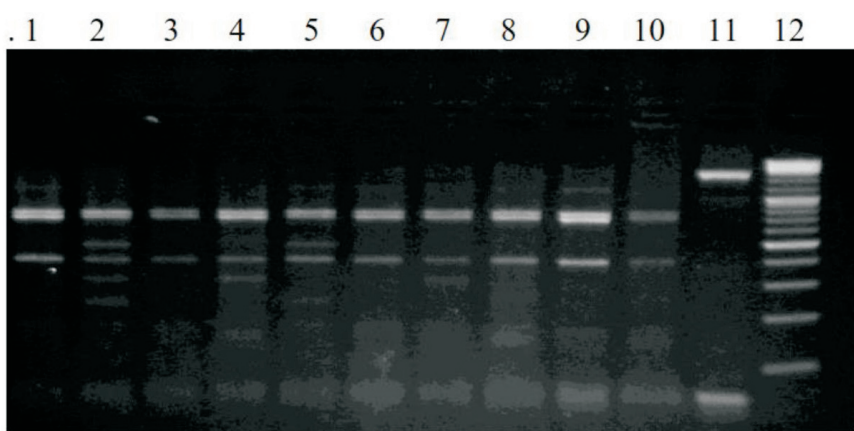

Fig. 3. Electrophoregramme of the restriction products of amplificated fragments of leptin gene of locus $L E P$

$(1,3,6,8,9,10$ - animals with genotype (AA 730 n.p., 690 n.p., 400 n.p. ); 4, 7 - animals with genotype $\mathrm{AB}$ (730 n.p., 690 n.p., 400 n.p., 310 n.p. and 90 n.p.); 5 - animals with genotype AC (730 n.p., 690 n.p., 470 n.p., 400 n.p. and 220 n.p.); 2 - animals with genotype BC (730 n.p., 690 n.p., 470 n.p., 310 n.p. and 90 n.p., 220 n.p.); 11 - PCR-product of amplification, 1820 n.p.; 12 - marker of molecular mass DNA Ladder)

gote CT and homozygote TT was almost identical - 46.7 and $40.0 \%$, respectively.

Cows of the same age of the red dairy breed had a slightly higher frequency (by 1.27 times) of allele $\mathrm{C}$ over $\mathrm{T}$ and there has a significant proportion of cows $(62.5 \%)$ that were heterozygotic for locus $L E P$.

Analysis of the real and expected heterozygosity does not reveal significant divergence in cattle of the three tested breeds, but higher real heterozygosity was found in cows of the Ukrainian Red Dairy breed, and higher expected heterozygosity for the other breeds. Considerable predominance of homozygotic over heterozygotic animals was shown by the fixation index for locus $L E P\left(F_{I S}=2.9 \ldots 19.4 \%\right)$, which was specific to breeds with red-speckled colour.

The pituitary transcription factor (Pit-1) is important in assessment of milk productivity. PCR of Pit- 1 was conducted by DNA amplification of fragment length 1355 n.p. (Anderson et al., 1994). Genotype AA was characterised by fragments - 660, 425, 270 n.p.; for BB - 660, 385 and 270

Table 5. Polymorphism by gene LEP of cows of Ukrainian breeds

\begin{tabular}{|c|c|c|c|c|c|c|c|c|c|c|c|c|c|}
\hline \multirow[t]{3}{*}{ Breed } & \multirow[t]{3}{*}{$n$} & \multicolumn{6}{|c|}{ Frequency of genotype } & \multirow{3}{*}{$\begin{array}{c}\text { Frequency } \\
\text { of allele } \\
\mathrm{C} / \mathrm{T}\end{array}$} & \multicolumn{2}{|c|}{ Heterozygosity } & \multirow[t]{3}{*}{$\chi^{2}$} & \multirow[t]{3}{*}{ PIC } & \multirow[t]{3}{*}{$F_{I S}$} \\
\hline & & \multicolumn{2}{|c|}{$\mathrm{CC}$} & \multicolumn{2}{|c|}{ CT } & \multicolumn{2}{|c|}{ TT } & & \multirow[t]{2}{*}{$H_{o}$} & \multirow[t]{2}{*}{$H_{e}$} & & & \\
\hline & & $n$ & $\%$ & $n$ & $\%$ & $n$ & $\%$ & & & & & & \\
\hline URD & 16 & 4 & 25.0 & 10 & 62.5 & 2 & 12.5 & $0.56 / 0.44$ & 0.625 & 0.508 & 1.165 & 0.492 & -0.230 \\
\hline URSD & 15 & 10 & 66.7 & 4 & 26.7 & 1 & 6.6 & $0.80 / 0.20$ & 0.266 & 0.311 & 0.417 & 0.320 & 0.194 \\
\hline UBSD & 15 & 2 & 13.3 & 7 & 46.7 & 6 & 40.0 & $0.37 / 0.63$ & 0.466 & 0.480 & 0.000 & 0.464 & 0.029 \\
\hline
\end{tabular}




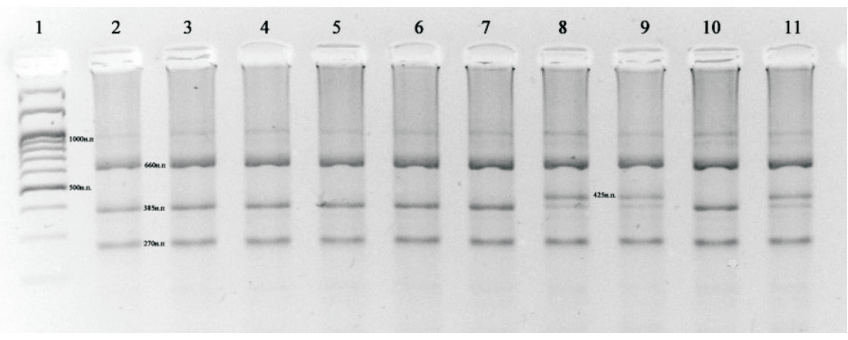

Fig. 4. Electrophoregramme of the products of restriction of amplificated fragments of gene Pit-1

(8, 9, 11 - genotype AB; 2, 3, 4, 5, 6, 7, 10 - genotype BB; PCR-product of amplification; $\mathrm{M}$ - marker of molecular mass)

n.p.; and for $\mathrm{AB}-660,425,385$ and 270 n.p. (Fig. 4). In the Ukrainian Red Dairy breed, the frequency of allele B was 2.22 times higher than for A. The frequency of homozygotes of allele A was 0.31 , though in fact the genotypes AA was not observed (Table 6).

Ukrainian Red-speckled Dairy cattle had identical frequency of the alleles A and B, with $60 \%$ of cows heterozygotic for locus Pit-1, and 20\% homozygotic (BB or AA).

For Ukrainian Black-specked Dairy cows, the frequency of allele A (0.37) was lower than for B (0.63) by 1.7 times and heterozygotes $\mathrm{AB}$ in the breed dominated (60\%). In all of the studied of dairy cattle breeds in the locus Pit-1 expected heterozygosity in fact was corresponding to estimated. There was a non-compliance with genetic equilibrium in the locus of hypophysar factor of transcription in favour of heterozygotes in cows of the three breeds (URD, URSD and UBSD), indicated by the fixation index with 40.9, 16.0 and $24.9 \%$, elimination of homozygotes.

The amplified gene fragment of thyreoglobulin had 548 n.p. The lengths of restricted fragments were: CC - three fragments 295, 178 and 75 n.p.; CT - four fragments of 473, 295, 178 and 75 n.p.; TT - two fragments 473 and 75 n.p. (Fig. 5).

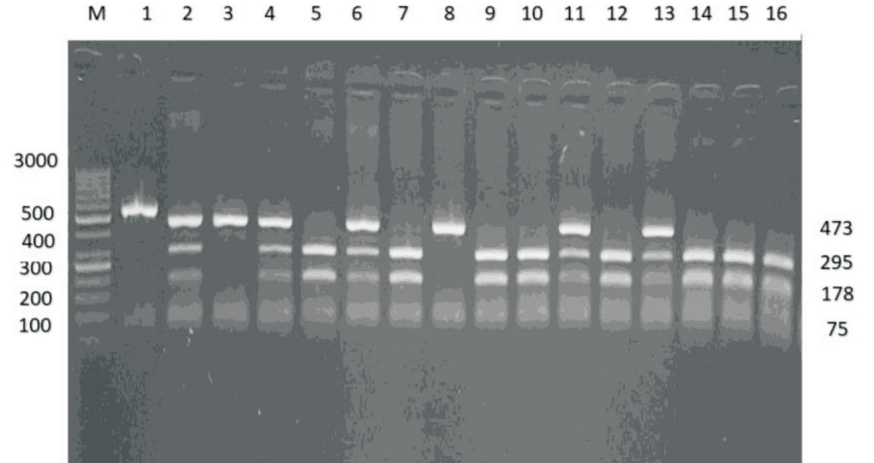

Fig. 5. Electrophoregramme of the restriction products of amplificated fragments of gene thyreoglobulin of locus $T G-5$

(1- amplificate; 2, 4, 6, 7, 8, 11, 13 - genotype CT; 3, 8-genotype TT; 5, $7,9,10,12,14,15,16$ - genotype CC; M - marker of molecular mass)

For locus TG-5, in all Ukrainian contemporary breeds of dairy cattle, a high frequency of allele $\mathrm{C}(0.91-0.97)$ was observed, and the frequency of homozygotes of this genotype was 0.812-0.933 (Table 7). For all estimated populations, expected and real heterozygosity of locus $T G-5$ differed and there was a displacement of genetic equilibrium in favour of heterozygotes in cows of breeds URD and URSD, indicated by the fixation index -6.9 and $3.6 \%$, respectively.

\section{DISCUSSION}

Polymorphic protein systems are the products of allelic genes of separate loci that in the process of selection are supported by selection (natural or artificial). Thus, every allele has a selective value, which may be shown in indices of productivity.

kappa-casein is a basic gene with quantative features, the polymorphism of which affects qualitative and quantitative indices of milk productivity. The product of gene amplification of CNS3 with primers includes the fourth exon and the

Table 6. Polymorphism by gene Pit-1 of cows of Ukrainian breeds

\begin{tabular}{|c|c|c|c|c|c|c|c|c|c|c|c|c|c|}
\hline \multirow[t]{3}{*}{ Breed } & \multirow[t]{3}{*}{$n$} & \multicolumn{6}{|c|}{ Frequency of genotype } & \multirow{3}{*}{$\begin{array}{c}\text { Frequency } \\
\text { of allele } \\
\text { A/B }\end{array}$} & \multicolumn{2}{|c|}{ Heterozygosity } & \multirow[t]{3}{*}{$\chi^{2}$} & \multirow[t]{3}{*}{$P I C$} & \multirow[t]{3}{*}{$F_{I S}$} \\
\hline & & \multicolumn{2}{|c|}{ AA } & \multicolumn{2}{|c|}{$\mathrm{AB}$} & \multicolumn{2}{|c|}{$\mathrm{BB}$} & & $H_{o}$ & $H_{e}$ & & & \\
\hline & & $n$ & $\%$ & $n$ & $\%$ & $n$ & $\%$ & & & & & & \\
\hline URD & 16 & 0 & - & 10 & 62.5 & 6 & 37.5 & $0.31 / 0.69$ & 0.625 & 0.444 & 3.306 & 0.430 & -0.409 \\
\hline URSD & 15 & 3 & 20.0 & 9 & 60.0 & 3 & 20.0 & $0.50 / 0.50$ & 0.600 & 0.517 & 0.600 & 0.500 & -0.160 \\
\hline UBSD & 15 & 1 & 6.7 & 9 & 60.0 & 5 & 33.3 & $0.37 / 0.63$ & 0.600 & 0.480 & 1.278 & 0.464 & -0.249 \\
\hline
\end{tabular}

Table 7. Polymorphism in gene $T G-5$ of cows of Ukrainian breeds

\begin{tabular}{|c|c|c|c|c|c|c|c|c|c|c|c|c|c|}
\hline \multirow[t]{3}{*}{ Breed } & \multirow[t]{3}{*}{$n$} & \multicolumn{6}{|c|}{ Frequency of genotype } & \multirow{3}{*}{$\begin{array}{c}\text { Frequency } \\
\text { of allele } \\
\text { A/B }\end{array}$} & \multicolumn{2}{|c|}{ Heterozygosity } & \multirow[t]{3}{*}{$\chi^{2}$} & \multirow[t]{3}{*}{ PIC } & \multirow[t]{3}{*}{$F_{I S}$} \\
\hline & & \multicolumn{2}{|c|}{$\mathrm{CC}$} & \multicolumn{2}{|c|}{ CT } & \multicolumn{2}{|c|}{ TT } & & $H_{o}$ & $H_{e}$ & & & \\
\hline & & $n$ & $\%$ & $n$ & $\%$ & $n$ & $\%$ & & & & & & \\
\hline URD & 16 & 13 & 81.2 & 3 & 18.8 & 0 & - & $0.91 / 0.09$ & 0.187 & 0.175 & 0.171 & 0.170 & -0.069 \\
\hline URSD & 15 & 13 & 86.7 & 2 & 13.3 & 0 & - & $0.93 / 0.07$ & 0.133 & 0.129 & 0.077 & 0.124 & -0.036 \\
\hline UBSD & 15 & 14 & 93.3 & 1 & 6.7 & 0 & - & $0.97 / 0.03$ & 0.066 & 0.067 & 0.018 & 0.064 & 0.000 \\
\hline
\end{tabular}


fourth intron of the gene. After restriction of this fragment by Hind III restrictase, two allelic variants A and B are produced. Variant B of gene CSN3 is characterised by two spot mutations in state 136 and 148, which arrest amino acid substitutions of Tyr for Iso and Ala for Asp (Kaminski et al., 1993). Gene CSN3 is associated with protein of milk and its coagulative characteristics. Allele B, one of the most valuable, is associated with a higher content of proteins and fat, as well as with optimum properties for production of cheese. Allele A influences the yield of milk, fat and protein (Tyulkin et al., 2005; Kalashnikova et al., 2006). Among different breeds for production, there is a preference for allele A over allele B (Tyulkin et al., 2005; Kalashnikova et al., 2006; Khaizaran et al., 2014; Pavlova et al., 2016), but some studies suggest the opposite (Kemenes et al., 1999; Lazebnaya et al., 2016).

There is a large amount of information on the relationships between genotypes (AA, $\mathrm{AB}$ and $\mathrm{BB}$ ) and yield and mass of fat and protein, cheese-suitability of milk and other features in different breeds of cattle (Nekrasov et al., 2017; Shendakova et al., 2014). It is known that the presence of allelic variant B in locus CSN3 is associated with increased content of casein proteins and higher biological value and milk with considerable amounts of all amino-acids (valine $-7 \%$, leucine $-12 \%$, lysine - $7 \%$ ). Irreducible amino-acids of casein are synthesised from free amino-acids of blood. Synthesis of milk proteins depends on nitrogen-containing substances of blood - amino-acids and polypeptides. A higher level of amino acids in blood plasma is associated with a higher protein content in milk. At the expense of increasing protein content in milk, the amounts of common proteins and amino-nitrogen in serum of blood become lower, which is explained by intensive protein metabolism for synthesis of milk protein.

Presence of allele B in locus $\kappa$-casein is associated with a trend of milk productivity. It is also economically important for production of cheese, as it improves the quality of hard cheese and accelerates the speed of curdling of milk. The allele is associated with increased content of casein proteins and milk fat, dry matter of milk, and also concentration of ionic $\mathrm{Ca}$, which is 13 times higher than in blood (Zhuravel et al, 1997). Animals which are homozygotic in allele A produce milk that has a low protein index, and retention in selection of this allele results in production of milk that is called "drinkable", but has poor (bad) technological features with low dry matter content (Epishko et al., 2010).

The next most important gene with effect on quantative and qualitative indices of milk is beta-lactoglobulin, the size of which is 4662 n.p.; it is formed from seven exons and six introns (Karimi et al., 2009). Allele BLG A has one restriction site for restrictase Hae III, which leads to formation of two restriction fragments - 148 and 99 n.p., and further restriction of the 148 n.p. fragment or forms two fragments with length 74 n.p. The gene of beta-lactoglobulin is polymorphine, which has allelic variants, the most common of which are variants A and B (Eigel et al., 1984; Tsiaras et al., 2005).
Beta-lactoglobulin gene is another genetic marker with significance for milk productivity and technological feartures of milk: allele $B L G \mathrm{~B}$ is associated with a higher content of casein proteins, high percent fat and better casein coagulation parameters. Presence of the $B L G$ igenotype in an animal is associated with a high content of serum proteins and higher common yield (Sheiko et al., 2009; Novikova et al., 2010). Serum proteins enter milk directly from blood, but in considerably less quantity. In this case, blood globulin transmutes into globulin of milk. Expression of variant B is linked with a high content of casein protein in milk, higher percent fat and better casein coagulation parameters. Variant $\mathrm{A}$ results in a high content of both serum proteins and total content of proteins of milk. In milk of cows with genotype $\mathrm{AB}$, both allelic forms of $B L G$ are present with preference of form A (Kim et al., 2001).

The leptin gene affects assimilation of nutrient matter, its metabolism and regulates the synthesis of fatty acids and their distribution in the organism. The content of triglicerides, which is the main component of milk fat, is reduced by increasing the yield. Some studies showed that allele T of the leptin gene is more desirable than allele $\mathrm{C}$, since allele $\mathrm{T}$ is associated with increased fat and protein content in milk, but some data shows that allele $\mathrm{C}$ is associated with increasing yields (Gonyon et al., 1987).

Glycerides of milk include in their composition greater quantities of low molecular weight fatty acids: saturated palmitic, stearin, and myristic; unsaturated - butyric, capronic, caprilic, and lauric.

At the starting stages of embryogenesis, the locus Pit- 1 is well-known to direct differentiation of hypophysis cells, determine development of the zones associated with synthesis of somatotropin, prolactin, and thyrotrop hormone, as well as regulate the activity of hormones that influence the level of yield and filtration and synthesis of components of milk in the udder. The allele A variant is associated with increased yield, and expression of the allele B is connected with increased content of fat in milk (de Mattos et al., 2004).

Another tested gene is $T G-5$ which is responsible for underskin ball and for common per cent of fat in tissues, including forming of milk, since iodotyronines influence on differentation of adipocytes (Kopylova et al., 2011). Thyreoglobulin is a glucoprotein hormone that is synthesised in follicular cells of the thyroid gland and is the precursor of tricodteranin and tetraiodteranin. It affects the percent fat content in tissues and participates in formation of triglycerids (Aihaund, 1992). The sources of light fatty acids of milk fat are acetic, propionic and butyric acids, but the glycerine part of milk fat is synthesised from carbohydrates. Therefore, fatty-milky cows have a low content of sugar in blood (Bogatova et al., 2004). It is also known that allele $\mathrm{T}$ is associated with greater content of fat in milk (Larionova, 2006). 


\section{CONCLUSIONS}

The study of polymorphisms of structural genes in native breeds (Ukrainian Red Dairy, Ukrainian Black-speckled Dairy, and Ukrainian Red-speckled Dairy) was based on the analysis of the distribution of allelic variants of genes CSN3, BLG, LEP, Pit-1 and TG-5 and analysis of breeds genotypes in connection with their unique phenotypic features. Our findings can be useful for cow selection by DNA markers in the following directions:

- increased yields of milk in the breeds Ukrainian Red Dairy $\left(C S N 3^{\mathrm{AA}}, T G-5^{\mathrm{SS}}\right)$, Ukrainian Black-speckled Dairy $\left(C S N 3^{\mathrm{AA}}, T G-5^{\mathrm{SS}}\right)$ and Ukrainian Red-speckled Dairy $\left(T G-5^{\mathrm{SS}}, \mathrm{LEP}^{\mathrm{SS}}\right)$;

- increased content of fat in milk - in breeds Ukrainian Red Dairy $\left(\right.$ Pit $\left.-1^{\mathrm{BB}}\right)$, Ukrainian Black-speckled Dairy $\left(B L G^{\mathrm{BB}} ; L E P^{\mathrm{TT}}\right)$ and Ukrainian Red-speckled Dairy $\left(B L G^{\mathrm{BB}}\right)$;

- better technological qualities of processing of milk for hard cheese - in the Ukrainian Red-speckled Dairy $\left(C S N 3^{\mathrm{BB}}\right)$;

- increased content of common protein in milk - in breeds Ukrainian Red Dairy $\left(B L G^{\mathrm{AA}}\right)$, Ukrainian Black-speckled Dairy $\left(L E P^{\mathrm{TT}}\right)$ and Ukrainian Red-speckled Dairy $\left(C S N 3^{\mathrm{BB}}\right)$;

- relatively greater content of cheese-serum protein of milk - in the breed of Ukrainian Red Dairy $\left(B L G^{\mathrm{AA}}\right)$. This breed may be used to form industrial groups or farms of definite assignment for obtaining milk raw material.

\section{REFERENCES}

Ailhaund, G. (1992). Cellular and molecular aspects of adipose tissue development. Annu. Rev. Nutr., 12, 207-233.

Alexander, G., Juvancz, Z., Szejtli, J. (1988). Cyclodextrins and their derivatives as stationary phases in GC capillary columns. J. Hing Resolut. Chromatogr. Commun., 11, 110-113.

Alison, V. E. (2007). Marker-assisted selection in beef cattle. Available from: https://www.agrireseau.net/bovinsboucherie/documents/ Marker_Assisted_Selection_in_Beef_Cattle.pdf (accessed 30.11.2020).

Anderson, B., Rosenfeld, M.G. (1994). Pit-1 determines cell typeduring development of the anterior pituitary gland. J. Biol. Chem., 269, 29335-29338.

Bogatova, O. V., Dogareva, N. G. (2004). Chemistry and Physics of Milk [Богатова О. В., Догарева Н. Г. Химия и физика молока]. Tutorial. Orenburg, 137 pp. (in Russian).

Eggena, F. R. (1989). Die Untersuchung von Kasein genes mittels DNA-Analyse. ETH Landwirtschaft Schweb, 2, 231-235.

Eigel, W. N., Butler, J. E., Ernstrom, H. M., Farell, Jr, V. R., Harwalkar, R., Jenness, R., Whitney, McL. (1984). Nomenclature of proteins of cow's milk: fifth revision. J. Dairy Sci., 67, 1599-1631.

Epishko, T. I., Tanana, L. A., Epishko, O. A., Peshko, V. V., Trakhimchik, R. V. (2010). Genetic resources of dairy cattle of Belarus on the kappa-casein gene and its association with milk productivity and technological properties of milk [Епишко Т. И.,Танана Л. А., Епишко О. А., Пешко В. В., Трахимчик Р. В. Генетические ресурсы молочного скота Беларуси по гену каппа-казеина и его ассоциация с молочной продуктивностью и технологическими свойствами молока]. [Breeding and Animal Genetics], 44, 73-76 (in Russian).

Godovac-Zimmermann, J., Krause, I., Buchberger, J., Weiss, G., Klostermeyer, H. (1990). Genetic variants of bovine beta-lactoglobulin. A novel wild-type beta-lactoglobulin $\mathrm{W}$ and its primary sequence. Biol. Chem. Hoppe-Seyler, 371, 255-260.

Kalashnikova, L. A., Trufanov, V. G. (2006). Influence of kappa-casein genotype on dairy productivity and technological properties of milk of cows of Holmogorsk breed [Калашникова Л. А., Труфанов В. Г. Влияние генотипа каппа-казеина на молочную продуктивность и технологические свойства молока коров холмогорской породы]. Reports of the Russian Academy of Agricultural Sciences [Доклады Российской академии сельскохозяйственных наук], 4, 43-44 (in Russian).

Kaminski, S., Figiel, L. (1993). Kappa-casein genotyping of Polish Blackand-White $\mathrm{x}$ Holstein-Friesian bulls by polymerase chain reaction. Genetica Polonica, 34, 65-72.

Karimi, K., Nasiri, M., Fayyazi, J., Mirzadeh, K. H., Roushanfekr, H. (2009). Allele and genotype frequencies of P-lactoglobulin gene in Iranian Najdi cattle and buffalo populations using PCR-RFLP. Afr. J. Biotechnol., 8 (15), 3654-3657.

Kemenes, P. A., Regitano, L. A., Rosa, A. M., Packer, I. U., Razook, A. G., Figueiredo, L. A., Silva, N. A., Etchegaray, M. A., Coutinho, L. L.(1999). $\mathrm{K}$-casein, $\beta$-lactoglobulin and growth hormone allele frequencies and genetic distances in Nelore, Gyr, Guzerị, Caracu, Charolais, Canchim and Santa Gertrudis cattle. Gen. Mol. Biol., 22 (4), 539-541.

Khaizaran, Z., Al-Razem, F. (2014). Analysis of selected milk traits in Palestinian Holstein-Friesian cattle in relation to genetic polymorphism. J. Cell Animal Biol., 8 (5), 74-85.

Kim, J. J., Park, Y. I. (2001). Current statys of quantitative trait locus mapping in lives-tock species-reviev. Asian-Australasian J. Anim. Sci., 14 (4), $587-596$.

Kopylova, K. V. (2011). DNA diagnostics of genetic resources of cattle. Author's abstract. Dis. for the degree of Doctor of Agricultural Sciences. Sciences: Institute of Animal Breeding and Genetics, nd. a. M.V. Zubets of National Academy of Agrarian Science of Ukraine. Chubinskoe, pp. 2-33 (in Ukrainian).

Kopylova, K. V., Dubin, O. V., Podoba, Y. V., Mostova, I. V., Dobryanska, M. L. (2011). Analysis of QTLs quantative loci by TG, CAPN1 530, MSTN markers in cattle. [Breeding and Animal Genetics], 45, 108-116 (in Ukrainian).

Larionova, P. V. (2006). Development and experimental testing of systems of analysis of polymorphisms of candidate genes for lipid metabolism in cattle [Ларионова П. В. Разработка и экспериментальная апробация систем анализа полиморфизма генов-кандидатов липидного обмена у крупного рогатого скота]. Author. diss. cand. Federal Research Center for Animal Husbandry named after Academy Member L. K. Ernst. Dubrovnik. 24 pp. Dubrovnik, 3-18 (in Russian).

Lazebnaya, I. V., Perchun, A. V. (2016). Research on cattle of the Buryat breed using candidate genes [Лазебная И. В., Перчун А. В. Исследование крупного рогатого скота бурятской породы с использованием генов-кандидатов]. Eurasian Union of Scientists (ESU) [Евразийский Союз Ученых (ЕСУ)], 31, 6-9 (in Russian).

de Mattos, K. K., Del Lama, S. N., Martinez, M. L., Freitas, A. F. (2004). Association of $\mathrm{b}$ GH and Pit-1 gene variants with milk production traits in dairy Gyr bulls. Pesq. Agropec. Bras. Brasilia, 39 (2), 147-150.

Medrano, J., Aguilar-Cordova, E. (1990). Genotyping of bovine BLG loci following DNA sequence amplification. Biotechnology, 8, 144-165.

Moody, D. E., Pomp, D., Barendse W. (1995). Restriction fragment length polymorphism in amplification products of the bovine Pit-1 gene and assignment of Pit-1 to bovine chromosome 1. J. Animal Genetics, 26, 45-47.

Nekrasov, D. K., Kolganov, A. E., Kalashnikova, L. A., Semashkin, A. V. (2017). Interrelation of polymorphic variants of prolactin, growth hor- 
mone and kappa-casein genes with milk productivity of cows of Yaroslavl breed [Некрасов Д. К., Колганов А. Е., Калашникова Л. А., Семашкин А. В. Взаимосвязь полиморфных вариантов генов пролактина, гормона роста и каппа-казеина с молочной продуктивностью коров ярославской породы]. Agr. Bull. Upper Volga Reg.[Аграрный вестник Верхневолжя], 1 (18), 40-48 (in Russian).

Novikova, N. V., Kanatpaev, S. M., Tyulebayev, S. D., Kononenko, S. I. (2010). The use of combinational variability in increasing the meat productivity of heifers [Новикова Н. В., Канатпаев С. М., Тюлебаев С. Д., Кононенко С. И. Использование комбинационной изменчивости в повышении мясной продуктивности телок]. Proc. Kuban State Agr. Univ. [Труды Кубанского государственного аграрного университета], 25 (4), 131-134 (in Russian).

Oblap, R. V., Novak, N. B. etc. (2010). Guidelines to the Use of the Method of Polymerase Chain Reaction in Animal Husbandry. Bila Tserkva. 66 pp. (in Ukrainian).

Oprzàdek, J., K. Flisikowski, L. Zwierzchowski, Dymnicki, E. (2003). Polymorphisms at loci of leptin (LEP), Pit1 and STAT5A and their association with growth, feed conversion and carcass quality in Black-and-White bulls. Animal Sci. Papers Rep., 21 (3), 135-145.

Pavlova, N. I., Filippova, N. P., Kurtanovov, H. A., Koryakina, L. P. (2016). Estimation of allelic and genotypic diversity of cattle of Yakutia by milk genes [Павлова Н. И., Филиппова Н. П., Куртанов Х. А., Корякина Л. П. Оценка аллельного и генотипического разнообразия крупного рогатого скота Якутии по генам молочности]. Science and Education [Наука и образование], No. 3, 22-127 (in Russian).

Pinder, S., Perry, B., Skidmore, C. (1991). Analysis of polymorphism in the bovine casein genes by use of the polymerase chain reaction. Anim. Genet., 22 (1), 2-7.

Pomp, D., Zou, T., Clutter, A. C. (1997). Rapid communication: Mapping of leptin to bovine chromosome 4 by linkage analysis of a PCR-based polymorphism. J. Animal Sci., 75 (5), 1427

Sheiko, I. P., Tanana, L. A., Epishko, T. I. et al. (2009). Methods of improving the quality of milk of cows of the Belarusian black-motley and red Belarussian breed group by using the genetic marker of the kappa-casein gene in breeding: recommendations [Шейко И. П., Танана
Л. А., Епишко Т. И. и др. Метод улучшения качества молока коров белорусской черно-пестрой и красной белорусской породной группь путем использования в селекиии генетического маркера гена каппаказеина: рекомендации]. Grodno. 32 pp. (in Russian).

Shendakova, T. A., Shendakov, I. A. (2014). Genetic and environmental factors in the breeding of black and variegated cattle [Шендакова Т. А., Шендаков И. А. Генетические и средовые факторы в селекции скота чёрно-пёстрой породы]. Biology in Agriculture [Биология в сельском хозяйстве], No. 2, 2-13 (in Russian).

Sulimova, G. E. (2004). DNA markers in genetic studies: types of markers, their properties and applications [Сулимова Г. Е. ДНК-маркеры в генетических исследованиях: типы маркеров, их свойства и области применения]. Journal of the Laboratory for Comparative Animal Genetics [Журнал Лаборатории сравнительной генетики животных], No. 1, 17-18 (in Russian).

Sulimova, G. E., Salmenkova, E. A., Politov, D. V., Zinchenko, V. V., Glazer, V. M. (2002). Workshop on DNA and Protein Polymorphism. A methodological manual for the Great Workshop on Genetics at the Department of Genetics. Biology Faculty, Moscow State University. 80 pp. (in Russian).

Tsiaras, A. M., Barbouli, G. G., Boscos, G. (2005). Effect of kappa-casein and beta-lactoglobulin loci on milk production traits and reproductive performance of Holstein cows. J. Dairy Sci., 3, 327-334.

Tyulkin, S. V., Akhmetov, T. M., Zagidullin, L. R., Rach'kova, E. N., Shaydullin, S. F., Hilmanov, Kh. Kh. (2016). Polymorphism of the kappa-casein gene in cattle herds of the Republic of Tatarstan [Тюлькин С. В., Ахметов Т. М., Загидуллин Л. Р., Рачкова Е. Н., Шайдуллин С. $\Phi .$, Гильманов Х. Х. Полиморфизм гена каппа-казеина в стадах крупного рогатого скота Республики Татарстан]. Scientific Notes KGAVM them. N.E. Bauman [Ученые записки КГАВМ им. Н.Э. Баумана], 255 (1), 148-151 (in Russian).

Zhuravel, E. V., Glazko, V. I. (1997). Distribution of allelic and genotypic frequencies by the kappa casein locus in different cattle breeds [Журавель Е. В., Глазко В. И. Распределение аллельных и генотипических частот по локусу каппа-казеина у различных пород крупного рогатого скота]. Genetics [Генетика], 33 (12) (in Russian).

Received 20 January 2020

Accepted in the final form 12 October 2020

\section{PROTEĪNU UN LIPĪDU VIELMAIN̦AS GĒNU POLIMORFISMS MODERNAJĀS UKRAINAS PIENA VIRZIENA LIELLOPU ŠKIIRNĒS}

Ar RFLP (Restriction Fragment Length Polymorphism) metodi noteikts polimorfisms proteīnu un lipīdu vielmaiņas gēnos CSN3 (kappa-casein), BLG (betalactaglobulin), LEP (leptin), Pit-1 (pituitery transcription factor), TG-5 (thyroglobulin) vairākām Ukrainas piena virziena liellopu škirnēm. 